\title{
PEDAGOGY
}

\section{Formation and development of educative capacity integration of family, school and community in Great Britain}

\author{
V. I. Boboshko \\ Pavlo Tychyna Uman State Pedagogical University, Uman, Cherkassy region, Ukraine, \\ Corresponding author. E-mail: toriia.boboshko@ukr.net
}

Paper received 22.01.18; Revised 25.01.18; Accepted for publication 28.01.18.

https://doi.org/10.31174/SEND-PP2018-154VI64-01

Abstract. The article deals with the illumination of experience of Great Britain in organized the participating of parents, teachers and public in management of school education. Genesis of becoming of this participation is traced, the basic forms of its realization are considered. It is found out, that most full the marked participation will be realized by creation school-boards, paternal and teaching associations that operate on a national and local level.

Keywords: Great Britain, parents, teachers, educative capacity integration, family, school, community.

Ukrainian society's publicity, broadening of its communication sphere with other folks, orientation to entrance into the European and world expanse create favourable opportunities for national upbringing system enrichment with the best achievements of the world culture. Nowadays study and analysis of advantages and disadvantages of both national and foreign educational systems of upbringing become a standard of scientific interaction between the countries and correspond to demands of mutual enrichment. School, family and local community become the first and the main models of social world for the child. The theory of modern upbringing of Great Britain takes an important place in the development of educative capacity integration of family, school and community.

However, there is a lack of experience of family's, school's and community's efforts combination according to child's formation and development in the national pedagogical theory and practice. Due to it, there is a necessity of studying a foreign experience, in particular of Great Britain, where child's upbringing is limited only with family frames and is changed with more perfect scheme, the basis of which is family's, school's and local community's efforts integration. The study of educative capacity integration peculiarities of these social institutions will allow receiving more entire image about its peculiar features in order to use it properly in the national upbringing system.

Such British scientists as J. Epstein, T. Parsons, Donald R. Winkler investigate the problems of parents, teachers and community interaction. They are convinced that the more teacher knows about child's life beyond school, the more he understands his needs and can organize upbringing process successfully, coordinate family's, school's and community's efforts in upbringing of the growing up personality. As a matter of fact the chain "pedagogue-pupils" always has one more element - "parents". That's why school will never become a school of joy for pupils without cooperation with parents; it will always be a strange place $[6 ; 9 ; 12]$.

There is a number of Ukrainian researchers who study the peculiarities of family upbringing in Great Britain. They are S. Chervonetska (upbringing of moral qualities of junior school children by means of nature in family in Great Britain) [15], O. Demchenko (historic pedagogical analysis of theory and practice of family upbringing in Great Britain) [14] and others.
British society is worried by numerous problems connected with family, which traditionally is believed to be a primary branch in children upbringing. Change of family traditional structure (absence of elderly people), reduce of family upbringing capacity, expansion of children homelessness, unsteadiness, high level of divorces, increase of one-parent families, increase of number of families with teenager mother, poverty and therefore bad training of children at school, drug and alcohol abuse - that is not the whole list of problems for solution of which all state and civil powers should be integrated.

Theory and practice of family upbringing in Great Britain has become an object of deep constructive critical analysis for the first time at the end of XIX -beginning of XX century. A great success of this state in economic, social and spiritual life made pedagogues and psychologists of different countries of those times to pay attention to analysis of the main factors of such progress and distinguish the most important factor among them - the system of upbringing organized in the corresponding way [14]. Researchers state that family is the basis of upbringing and education of the rising generation for the British. Good friendly relations, mutual love and respect, which create the most favourable conditions for upbringing, are changeless motto of the folk pedagogy.

British family is an embodiment of society, which permanently creates, supports and experiences on itself its relevant converse influence. This mutual influence assures society steadiness, certain integrity and identity of views on accommodation facilities, values system, ideals and intentions. The distinguished elements of existence are kept and delivered from generation to generation through traditions, customs, cultural achievements, which are greatly honoured by the British. They also pay a special meaning to the formation of human qualities of the young generation. These qualities should be constructed on the basis of high moral ethical and spiritual ideals [16].

The Ministry of Education is the governing body of education management at the national level in Great Britain. The Minister of Education is the head of it. He is appointed by her Majesty the Queen of Great Britain. The Ministry of Education is responsible for implementation of the national policy in education sphere; it manages the activity of the existing educational establishments of the country. Local bodies of education management are subordinate to the 
Ministry of Education and perform powers, conferred by the Ministry. The main task of education management at the local level is realization of the national educational policy taking into account regional peculiarities. Local authorities play a great role in conduction of managerial functions in the country.

The study of the history of educational system in Great Britain shows that two traditional directions always dominated in it. They are: a good general educational development in grammar and other types of luxury schools, which have theoretic specialization and a weak general educational development with great advantage of professional specialization at secondary schools.

In 1902 The Law on Education ("The Law of Belfur") was adopted in Great Britain. According to it school committees have been cancelled and local bodies of education management have been implemented into the pedagogic system instead. New local authorities of education management took over the curriculum of church schools and supported them financially. Thanks to their activity the first and the second stages of education at the British schools have been implemented. The Act on Education of 1902 started the creation of the national system of general secondary education and organization of the pedagogical process at schools of Great Britain on the basis of integrated demands [3].

The Ministry of Education started implementing modern approaches to pedagogical process organization. They are as follows: according to regulatory documents of 1905 teachers had to organize pedagogical process in such way to prepare pupils for decent life as citizens of their country as well as to independent living and reasonable use of free time; teachers have to adjust curriculum to pupils' needs; according to the Law on Education of 1907 the task was to improve the quality of primary education as well as to give scholarship for talented pupils to study at secondary school; a system of pupils' education at primary school to the age of 11 years has been created since 1910; the Examination Council of secondary schools of Great Britain, which controlled the process of certificate obtainment by pupils after secondary school leaving, was created in 1917 [1, p.8].

Essential modernization changes, concerning English school, especially extension of its interaction with parents and public, were established by the Law on Education of 1944 [4]. "The Law of Butler", which almost completely changed legislation of pedagogical process organization at British schools and redistributed the responsibility for management of the national educational system among central government, which works out school national policy in this sphere, local authorities of education management, which work out and introduce regional educational policy and schools, the administration of which manages school pedagogic process and controls the resources, coming from central and local budgets. This Law defines the necessity of support and development of the institute of managers or school council members. The councils' structure for different types of schools and the order of their functioning have been established by the Law. The role of local authorities in school councils' organization and proportional balance of local management bodies representation in school councils' structure have been defined.

The Law on Education of 1944 proclaimed that local educational management bodies had to control the fulfil- ment of the national educational policy in counties and separate schools. In particular, they had to appoint teachers and pay salary as well as to divide resources between schools, including charges for teachers' salary, school buildings and means of education [15].

The Law on Education of 1944 caused essential changes in pedagogical process organization at British schools. Head teachers were able to control the fulfilment of curriculum and divide school resources by themselves. Teachers also received more freedom in pedagogical process realization, especially it referred to learning material structuring, textbooks and training resources selection, etc.

Although the quantity of associations of parents and teachers greatly increased at the end of 1940 - beginning of 1950 , there wasn't any central body, which could coordinate their activity. At the same time the union of separate associations into the National Coordination Centre could be seen. Representatives of different regions created a single body of management - the State Federation of Parents and Pedagogues.

In the 60-s of the XX century local educational management bodies of Great Britain decided to change school system from two level (primary and secondary) into three level one (primary, secondary (intermediate) and high schools) [7, p. 5].

Further development of school and family cooperation in Great Britain is connected with the report "Children and primary school” (1967 p.) [10, p. 551], where different types of teachers and parents interaction (associations of teachers and parents, meeting of parents with teachers, information for parents, teachers' visits to pupils' families) have been highlighted. The program on coordination of family and primary school relations has been proposed. It aimed at such positions observing:

1) organization of regular meetings of parents and class teachers;

2) individual conversations with parents;

3) preparation of regular written reports on every child by school;

4) organization of extracurricular activities with the aim of effective use of children's leisure, parents' involvement into the more active participation in the school life.

The report "Primary education in Wales" emphasized on the importance of close cooperation and information exchange between school and family [5, c. 26].

Decentralizing aspects of education management are reflected in the high competence of local bodies according to the school network development, schools equipping with pedagogical staff, subsidy division, responsibility for education contents and quality, control for curricula and programs, which are implemented at schools. In terms of autonomy, school administration and teachers show high initiative in curriculum and study programs working out, effective decisions adoption towards educational process organization. However, low education quality, which exists under such conditions, caused strict criticism of decentralization aspects in education management. In the result, since the end of 70-s of the XX century the tendency towards education management centralization has enforced, the role of central education management bodies in its quality assurance has increased.

Attention to family and school integration, implementation of parents and teachers cooperation on the basis of 
democratic principles falls within 70-s of the XX century. Until this time parents were not included into educational policy and practice, and teachers tried to hold down their interference into the education system activity. Eventually some local management bodies started to appoint parents to be school council members; the suggestion to create a representative body at the local level - a school council, in which parents were equal partners - appeared in 1977.

At the beginning of 80 -s of the XX century a number of government documents were adopted. They demanded proclamation of intentions towards curriculum realization at British schools from the local education management bodies.

Thanks to reformation measures of 1980 parents of the British pupils received more opportunities to influence on the pedagogical process and control its quality. They were involved into school administration. Parents got the right to choose school for their children.

In the 1980-s in order to make the positions of local management bodies, who supported Labour Party, weaker and enhance the process of implementation of democratic principles into their activity, the British government involved parents to school management by means of their inclusion into the school councils.

The Central Government decided to reduce the teacher's influence on creation of the curriculum and the School Councils, in which teachers had great authority, were cancelled in 1984. The curriculum was controlled by the school examination council, members of which were appointed by the State Secretary as well as by the School Curriculum Council, which wasn't a state structure. The duty according to pedagogical process organization was divided between the Central Government, local education management bodies and schools. It was recommended to involve pupils' parents to this process a lot. In the result of these measures local education management bodies' authority was weakened [11, c. 49].

General tendencies of school education democratization as a whole and pedagogical process at secondary educational establishments in particular were enhanced with the legislative Law on Education of 1986. It contained such guidelines: to oblige local education management bodies to determine education policy; to increase the level of parents' authority in pedagogical process organization at schools; to appoint administrative body at every school, which is under the jurisdiction of local education management bodies; to oblige school administration to publicize the report on pedagogical activity and to conduct parent meetings annually; to create the council, which will include representatives of local education management bodies as well as representatives of business and industrial structures at every school etc. [2, c. 25].

In 1988 the Law on Education was adopted, which was called "Baker's Law" and became one of the most important legislative laws after the Law on education of 1944. Changes, foreseen with this document, referred such issues of the national education system as: national curriculum, testing system, new approaches to religion study, local school management, school administration, education standards, school grants, city technological colleges [2, c. 26].

As a result of reform of 1988, which fixed the way of school councils' formation, determination of their quantita- tive and qualitative structure at the legislative level, councils receive great authority, dividing responsibility for school management with head teacher and senior school managers.

A great attention in "Baker's Law" was paid to the issue of local school management. Schools of Great Britain till 1988 controlled expenses only for textbooks and visual materials. Selection of pedagogical staff and school rooms were controlled by the local education management bodies. Thanks to legislative reinforcement of the local management, schools received more authority; in particular they started to control almost the whole school budget. Headmasters turned into managers, who studied the procedures of staff integration, schools managing etc. So, the control for the school budget transferred from local education management bodies to schools immediately

In 1988 the government of Great Britain allocated funds especially for preparation course for school councils' participants. In the result, the quantity of local bodies, which suggested the corresponding training at different courses and introductory sessions, increased to $82 \%$ from their general quantity. Short term courses were mostly wide spread. They were carried out before school councils' meetings as well as the courses, which functioned on the basis of schools.

As we can see, the intention of education improvement and its quality increase caused the necessity of reformation of education management system in Great Britain. The analysis of reforms of the second half of the XX century has given grounds to establish the tendency for implementation of centralization and decentralization ways of management, which take up top-priority positions in the education quality assurance.

School councils are responsible for school budget formation as well as for working out of policy and determination of the main activity direction of school. All these issues are solved in the process of consulting with head teacher and senior lecturers. The authority of such councils include: approval of teachers on positions, issues solutions concerning salary, control for national curriculum fulfilment, support of parents' certainty in the fact that they are aware of all the aspects of school work, pupil's exclusion for bad behavior.

Schools are subordinate to school council, which, in its turn, is responsible for parents and local management bodies. These councils have a great autonomy; however this autonomy reinforcement may cause power reinforcement of head teacher, who often has a great influence on school council's decisions [13, c. 116].

Legislative assurance of modern school pedagogical process in Great Britain foresees autonomous management organization in every country, which is a part of the United Kingdom: England, Wales, Scotland and Northern Ireland. Children, Schools and Family State Secretariat as well as Innovation Implementation Secretariat are responsible for education process organization at schools in England, Wales and Northern Ireland. In Scotland Education and Lifelong Learning Secretariat is responsible for similar things in the Scottish Parliament. Local education management bodies provide for the current administering and financing of state schools. In the countries of the United Kingdom pedagogical process at schools is organized and fulfilled under the authority of local administrations [8]. 
Thorough study and analysis of the active legislation of Great Britain made it possible to determine that this country has clearly defined tendencies of family and school convergence. All participants of the bringing up process, first of all parents, teachers, civil organizations and community, realized the necessity of close mutual cooperation.

\section{REFERENCES}

1. Board of Education : Reports on children under five years of age in public elementary schools, by Women Inspectors Cd 2726. London: HMSO, 1905.

2. Chitty C., Dunford J. State schools: New Labour and the Conservative legacy. London: Woburn Press, 1999.

3. Education Act 1902 [Electronic resource]. - URL : http://www.dg.dial.pipex. com/history/text03.shtml.

4. Education Act 1944 [Електронний ресурс]. - Режим доступу: http://www.legislation.gov.uk/ukpga/Geo6/7$8 / 31 /$ contents/enacted

5. Edwards V., Redfern A. At home is school. Parents participation in primary education. London, New-York, 1988.

6. Epstein J., Salinas K. Partnering with families and communities. Educational leadership. Alexandria. 2004. Vol.61. №8.

7. Hargreaves David H. Social Relations in a Secondary School. Florence, KY: Routledge, 1998.

8. McLean M. Comparative Perspectives in Curriculum Concepts and Structures. Moscow, 1991.

9. Parsons T. The Social System. Glencor III, 1957.
10. Plowden C. Children and their primary schools Report of the Central Advisory Council for Education (England). London: HMSO, 1967.

11. Shipman M. Education as a public service. London: Harper and Row, 1984.

12. Winkler Donald R. Strengthening Accountability in Public Education. [Електронний pecypc]. - Режим доступу: http://www.equip123.net/docs/e2AcctPublicEd_PolicyBrief.pdf

13. Demchenko O. Pro spivpratsyu sim"yi i shkoly u spravi vykhovannya pidrostayuchoho pokolinnya u Velykiy Brytaniyi. Naukovi zapysky Ternopil's'koho ped. un-tu im. V.Hnatyuka. Seriya 3: Pedahohika i psykholohiya. Ternopil', 1998.

14. Postolenko I. S. Reformuvannya shkil'noyi osvity Anhliyi v druhiy polovyni KhKh stolittya. Sotsializatsiya osobystosti: zb. nauk. pr. K.: NPU, 2006.

15. Chervonets'ka S.S. Dukhovno-moral'ne vykhovannya ditey u sim"yi v svitli pravoslavnykh idealiv. Dukhovnist' osobystosti: metodolohiya, teoriya i praktyka: zb. nauk. pr. Vyp. 3 (16). Luhans'k: Vyd-vo SNU im. V.Dalya, 2006.

\section{Генезис становления и развития интеграции воспитательного потенциала семьи, школы и общества в Великобритании} В. И. Бобошко

Аннотация. Статья посвящена рассмотрению особенностей интеграции семьи, школы и общества в государственной политике Великобритании и их участия в управлении школьным образованием. Прослежено историческое развитие становления этого участия, рассмотрены основные формы ее реализации, традиции взаимодействия родителей, учителей, представителей общественных организаций и местных органов управления и представлены их сущностные характеристики для адекватного использования в национальной системе воспитания.

Ключевые слова: Великобритания, родители, учителя, местные органы управления, общественность, взаимодействие. 